\title{
Pawpaw (Carica papaya) seeds powder in Nile tilapia (Oreochromis niloticus) diets: 2 Liver status, sexual hormones and histological structure of the gonads
}

Fathy F. Khalil, Fayek H. Farrag, Ahmed I. Mehrim and Mohamed M.A. Refaey Animal Production Dept., Fac. Agric., Mansoura Univ., Mansoura, Egypt

\section{ABSTRACT}

The present study was carried out to evaluate the ability of using Pawpaw (Carica papaya) seeds powder (PSP) as natural reproductive inhibitor for Nile tilapia (Oreochromis niloticus) to control their propagation. The experiment was divided into two periods; the first was the treating period $\left(1^{\text {st }}\right)$ during which the Nile tilapia fry were treated with PSP for 71 days and the second was the rearing period whereas the Nile tilapia fingerlings $\left(2^{\text {nd }}\right)$ obtained from the first period until sexual maturation stage for 84 days. The PSP was added to the basal diet at levels of 0, 2, 4, 6 and $8 \mathrm{~g} / \mathrm{kg}$ diet for 15, 30, 45 and 60 days, different periods $\left(1^{\text {st }}\right)$. Results of the $2^{\text {nd }}$ period showed that there were no significant $\Varangle \mathrm{P} 0.05)$ effects on total cholesterol, testosterone and progesterone hormones among all periods; however the testosterone and progesterone hormones were decreased ( $\mathrm{E}-0.01$ 1) by increasing levels of PSP. Also, the high levels of PSP (4, 6 and $8 \mathrm{~g} / \mathrm{kg}$ diet) and increasing exposure periods (30, 45 and 60 day) caused obvious histological alternations of testes and ovaries of $O$. niloticus which reduce the fertility of both males and females. Consequently, it could be recommended that the effectiveness use of PSP as a natural reproductive inhibitor for $O$. niloticus.

Keywords: Nile tilapia, Pawpaw seeds powder, Sexual hormones, Gonads histology

\section{INTRODUCTION}

Tilapia species constitute a major and important item in the Egyptian fish farming. It displays many favourable attributes as culture species, on the basis of its general hardness, resistance to diseases, high yield potential and ability to grow on a wide range of natural and cheap artificial foods. Additionally, it also can withstand low oxygen concentrations, overcrowding, tolerate difficult ecological conditions and a wide range of salinities and still produce a highly acceptable flesh (El-Sayed, 2006). So, tilapias are the second only to carps as the most widely farmed freshwater fish in the world (FAO, 2010). In Egypt, the total production of tilapia fish increased from 78.35 thousand tons in 1980 to 730.8 thousand tons in 2011, which consider as approximately 53.65\% of the total fish production (GAFRD, 2011).

Now, tilapias did not reach their full aquaculture potential. This problem is reflection to the precocious maturity and uncontrolled reproduction which often let to overpopulation of production ponds with young (stunted) fish (Jegede and Fagbenro, 2008). Tilapia starts breeding even when three months old at $8 \mathrm{~cm}$ size onwards (Guerrero, 1982). Generally, at first maturation, the Nile tilapia females under aquaculture conditions in a range of 30 to 50 g weight (Mansour, 2001). Consequent, within a few months of culture the pond gets full with small fishes resulted in overpopulation, slow growth and the income of the fish farms gets very little or no profit (Guerrero, 1982). Where, overpopulation results from the uncontrolled reproductive lead to stunted growth, with normal production of fish with low nutritional and commercial values (Beardmore, 1996). Control population methods in tilapia farm have been reviewed (Guerrero, 1982 and Fagbenro, 2002). They indicated 
to the effective of monosex culture, sex reversal, cage/tank culture, use of predators, high density stocking, sterilization, intermittent/selective harvesting and use of slow maturing tilapia species. However, all these methods have their limitations; e.g. use of reproductive inhibitors (chemosterilants and irradiation) has disadvantages of expensive technology, hatchery facilities and skilled labour are required, and hormones are expensive and difficult to obtain (Jegede and Fagbenro, 2008).

Recent years, medicinal plants have successfully been used to induce sterility in laboratory animals (Das, 1980). One of this plants is pawpaw (Carica papaya) seeds had been used as fertility control agents in some laboratory animals as rats (Udoh et al., 2005b), rabbits (Pathak et al., 2001) and langur monkeys (Lohiya et al., 2002). In the same trend, many researchers used pawpaw seeds powder (PSP) as a natural reproductive inhibitor in Nile tilapia (Ekanem and Bassey, 2003; Ekanem and Okoronkwo, 2003; Jegede and Fagbenro, 2008 and Abbas and Abbas, 2011). Most of the studies have been used pawpaw seeds as reproductive inhibitors in adult tilapia stage after sexual maturation. The obtained results of these studies showed the larval stages of many teleost species contain both ovarian and testicular tissues, with sexual differentiation commences shortly after hatching or after the initiation of feeding (Yamazaki, 1983). Therefore, the objectives of the present work were to assess the ability of using PSP as natural reproductive inhibitors for Nile tilapia (Oreochromis niloticus) to control their propagation, as well as its effect on plasma sex hormones and histological structure of gonads.

\section{MATERIALS AND METHODS}

The present study was carried out in Fish Research Laboratory, Animal Production Department, Faculty of Agriculture, Mansoura University, Dakahlia governorate, Egypt. This experiment was divided into two periods.

\section{Treating period with PSP $\left(1^{\text {st }}\right.$ period $)$ :}

Apparent-healthy 1200 Nile tilapia (O. niloticus) one day old fry, after absorbing the yolk sac (average initial body weight of $0.012 \mathrm{~g} /$ fry), were obtained from Fish Hatchery Laboratory, Animal Production Department, Faculty of Agriculture, Mansoura University. Fry were randomly distributed to 20 treatments (three aquaria were allocated for one treatment). Fry were stocked at a rate of 30 fry/glass aquarium (90 × $40 \times 50 \mathrm{~cm}$ ). Each aquarium was supplied with $108 \mathrm{~L}$ dechlorinated tap water and an air stone connected to small electric compressor. The experimental design is shown in Table (1).

Table 1: Details of the experimental design for treatments in treating $\left(1^{\text {st }}\right)$ and rearing $\left(2^{\text {nd }}\right)$ periods

\begin{tabular}{|c|c|c|c|}
\hline Treat. & Details & Treat. & Details \\
\hline $\mathrm{T}_{1}$ & 0 g PSP / kg diet for 15 days & $\mathrm{T}_{11}$ & 4 g PSP / kg diet for 45 days \\
\hline $\mathrm{T}_{2}$ & 0 g PSP / kg diet for 30 days & $\mathrm{T}_{12}$ & $4 \mathrm{~g}$ PSP / kg diet for 60 days \\
\hline $\mathrm{T}_{3}$ & 0 g PSP / kg diet for 45 days & $\mathrm{T}_{13}$ & 6 g PSP / kg diet for 15 days \\
\hline $\mathrm{T}_{4}$ & 0 g PSP / kg diet for 60 days & $\mathrm{T}_{14}$ & 6 g PSP / kg diet for 30 days \\
\hline $\mathrm{T}_{5}$ & 2 g PSP / kg diet for 15 days & $\mathrm{T}_{15}$ & 6 g PSP / kg diet for 45 days \\
\hline $\mathrm{T}_{6}$ & 2 g PSP / kg diet for 30 days & $\mathrm{T}_{16}$ & 6 g PSP / kg diet for 60 days \\
\hline $\mathrm{T}_{7}$ & 2 g PSP / kg diet for 45 days & $\mathrm{T}_{17}$ & $8 \mathrm{~g}$ PSP / kg diet for 15 days \\
\hline $\mathrm{T}_{8}$ & 2 g PSP / kg diet for 60 days & $\mathrm{T}_{18}$ & $8 \mathrm{~g}$ PSP / kg diet for 30 days \\
\hline $\mathrm{T}_{9}$ & 4 g PSP / kg diet for 15 days & $\mathrm{T}_{19}$ & $8 \mathrm{~g}$ PSP / kg diet for 45 days \\
\hline$T_{10}$ & $4 \mathrm{~g}$ PSP / kg diet for 30 days & $T_{20}$ & $8 \mathrm{~g}$ PSP $/ \mathrm{kg}$ diet for 60 days \\
\hline
\end{tabular}


Ripe fruits of pawpaw (C. papaya) were obtained from local market in Sharkia governorate, Egypt, to get the seeds. Then, the seeds were cleaned and shade-dried in dry oven at $50^{\circ} \mathrm{C}$ for 72 hours. The dried seeds were milled into fine particles size ( $<$ $250 \mu \mathrm{m})$; and kept in a dry, air-tight transparent plastic container. The chemical analysis of PSP used in the present study was $92.23 \%$ dry matter (DM); $22.56 \%$ crude protein (CP); $22.20 \%$ ether extract (EE); $7.97 \%$ ash and $47.27 \%$ total carbohydrate.

The formulation and chemical analysis of the basal diets used in $1^{\text {st }}$ and $2^{\text {nd }}$ periods are shown in Table (2). The basal diet was prepared by mixing the dried ingredients with oil before starting the experiment. The PSP was supplemented to the basal diet at levels $0,2,4,6$ and $8 \mathrm{~g} / \mathrm{kg}$ diet. The mash diet was given manually to fry four times daily at 9.00 a.m., 11.00 a.m, 13.00 p.m and 15.00 p.m., for six days a week for examined different periods 15, 30, 45 and 60 day. Fry were fed during the first 45 days at the rate of $30 \%$ of total body weight, and then the rate of feeding was reduced gradually to $15 \%$ until the 71 day (the end of the first period).

Table 2: Formulation (\%) and chemical analysis of experimental diet at the treating and the rearing periods

\begin{tabular}{|c|c|c|}
\hline Ingredients & $\begin{array}{l}\text { Experimental diet at the } 1^{\text {st }} \\
\text { period }\end{array}$ & $\begin{array}{l}\text { Experimental diet at the } \\
2^{\text {nd }} \text { period }\end{array}$ \\
\hline Fish meal & 46 & 15 \\
\hline Soybean meal & 30 & 35 \\
\hline Wheat bran & - & 16 \\
\hline Crushed corn & 20 & 25 \\
\hline Corn oil & 3 & 5 \\
\hline Molasses & - & 3 \\
\hline Premix ${ }^{1}$ & 1 & 1 \\
\hline \multicolumn{3}{|l|}{ Nutrients composition (\% dry matter basis) } \\
\hline Dry matter (DM) & 92.87 & 89.81 \\
\hline Crude protein (CP) & 37.53 & 27.89 \\
\hline Ether extract (EE) & 5.23 & 6.59 \\
\hline Ash & 10.75 & 11.12 \\
\hline Total carbohydrates & 46.49 & 54.40 \\
\hline Gross energy (Kcal / 100 g DM) ${ }^{2}$ & 451.4 & 442.9 \\
\hline Protein / energy ratio (mg CP / Kcal GE) ${ }^{3}$ & 83.14 & 62.97 \\
\hline
\end{tabular}

1- Premix containing per $1 \mathrm{~kg}$ : A vit. (15 million I.U.), E vit. (15 mg), B1 vit. (1.0 mg), B12 vit. (5.0 mg), K3 vit. (2.5 mg), B6 vit. (2.0 mg), Pantothenic acid (10.0 mg), Folic acid (1.2 mg), Biotin (0.05 mg) and D3 vit. (3.0 million I.U.). Copper (7.0 mg), Manganese (100.0 mg), iodine $(0.4 \mathrm{mg})$, Iron (40.0 mg), Zinc (50.0 mg), Selenium (0.15 mg) and anti- oxidant (125.0 mg).

2- GE $(\mathrm{Kcal} / 100 \mathrm{~g} \mathrm{DM})=($ CP $\times$ 5.64 $)+($ EE $\times$ 9.44 $)+($ Total carbohydrates $\times 4.11)$ calculated according to NRC (1993).

3- P/E ratio (mg protein/Kcal gross energy) $=$ CP/GE $\times 1000$

Fish wastes were accumulated and removed from each aquarium two days a week by siphoning of $20 \%$ of the water volume per aquarium, then, equal volume of water was replaced by dechlorinated tap water. The water was aerated by using air pump to permit suitable level of dissolved oxygen for Nile tilapia fry rearing. The dissolved oxygen was in normal range $6-8 \mathrm{mg} / \mathrm{L}$, and water temperature was maintained at $25-27^{\circ} \mathrm{C}$ during the experimental period. Light period was controlled to provide a $14 \mathrm{~h}$ light: $10 \mathrm{~h}$ dark daily. 


\section{Rearing period ( $2^{\text {nd }}$ period):}

At the end of the first period, the Nile tilapia fingerlings with an average body weight $4.674 \pm 1.99 \mathrm{~g}$ were randomly selected from each treatment and stocked at rate of 25 fish / tank (two replicates per treatment) for 84 days rearing period. Each tank (1 $\mathrm{m}^{3}$ in volume) was supplied with an upper irrigation open (inlet), an under drainage (outlet), and an air stone connected to electric compressor.

The basal diet in rearing period ( $2^{\text {nd }}$ period) was prepared by mixing the dried ingredients with oil, and pelleted by manufacturing machine (pellets size $1 \mathrm{~mm}$ ). During the rearing period diet was given six days a week at a rate of $8 \%$ of fish live body weight during the first 4 weeks, and then at a rate of $6 \%$ during the second 4 weeks and at a rate of $5 \%$ until the end of the experiment. Experimental diets were introduced manually twice daily at 8 a.m. and 14.00 p.m. The amount of feed was adjusted bi-weekly based on the actual fish body weight changes. The water temperature during this experiment ranged $24-25^{\circ} \mathrm{C}$. The photoperiod was controlled by timer provide $14 \mathrm{~h}$ light: $10 \mathrm{~h}$ dark daily during the rearing period.

At the end of the rearing periods, blood samples of fish (5 fish / tank) were collected from the caudal peduncle in all treatments. Adequate amounts of whole blood were withdrawn in small plastic vials containing sodium citrate (4\%) and transferred for centrifugation at $3500 \mathrm{rpm}$ for $15 \mathrm{~min}$ to obtain blood plasma, which were kept in deep freezer $\left(-20^{\circ} \mathrm{C}\right)$ till the biochemical analysis. Plasma samples were used for determination of aspartate aminotransferase (AST), alanine aminotransferase (ALT) (Reitman and Frankel, 1957) and total cholesterol (Ellefson and Caraway, 1976), using commercial test kits by a spectrophotometer (model 5010, Germany). Also, steroids sex hormones (progesterone and testosterone) were determined in plasma using commercial ELISA test kits catalog No. BC-1113 (BioCheck, Inc) and BC-1115 (BioCheck, Inc), respectively according to Tietz (1995).

Also, at the end of all the rearing periods ( $2^{\text {nd }}$ period), six fish (three $\delta$ and three ) per tank were randomly chosen and then individually weighed. Livers and gonads were removed and weighed to calculate hepatosomatic index (HSI) and gonadosomatic index (GSI) as the following equations:

Hepatosomatic index $(\mathrm{HSI})=($ Liver weight $/$ fish weight $) \times 100$ (Jangaard et al., 1967).

Gonadosomatic index $(\mathrm{GSI})=($ Gonads weight/fish weight $) \times 100($ Tseng and Chan, 1982).

Then, fish were sacrificed and the target organs (gonads) were sampled. These, samples were fixed in $10 \%$ neutralized formalin solution followed by washing with tab water, then dehydrated by different grades of alcohol (70, 85, 96 and 99\%). Samples were cleared by xylene and embedded in paraffin wax. The wax blocks were sectioned to six microns. The sections were stained by hematoxyline $(\mathrm{H})$ and eosin (E) stains and then subjected to a histological examination for gonads according to Roberts (2001).

The data were statistically analyzed by using SAS (2006), with factorial design (5X4) and evaluated by using the following model:

$$
\mathrm{Y}_{\mathrm{ijk}}=\mu+\mathrm{L}_{\mathrm{i}}+\mathrm{B}_{\mathrm{j}}+\mathrm{LB}_{\mathrm{ij}}+\mathrm{e}_{\mathrm{ijk}}
$$

Where, $\mathrm{Y}_{\mathrm{ijk}}$ is the data of plasma liver enzymes, total cholesterol and sexual hormones, $\mu$ : the overall mean, $\mathrm{L}_{\mathrm{i}}$ : the fixed effect of the dietary PSP, $\mathrm{B}_{\mathrm{j}}$ : the fixed effect of different periods, $L B_{i j}$ : the interaction effect between dietary PSP levels with different periods and $\mathrm{e}_{\mathrm{ijk}}$ : the random error. The differences between mean were statistically compared for the significance ( $\mathbb{E}$ 0.05) using Duncan (1955) multiple range test. The interaction between the dietary levels of PSP and different periods 
were statistically compared for the significance (ㅌ 0.05) using Tukey 's multiple ranges test.

\section{RESULTS}

\section{Hepatosomatic index (HSI) and liver enzymes:}

Effect of levels of PSP at different exposure periods on HSI (male and female) and liver enzymes (AST and ALT) during the rearing period were illustrated in Table (3). Concerning the different periods, the males treated for 30 days with PSP recorded the highest $(\mathrm{P} \leq 0.05)$ values in HSI compared with different periods. However, the HSI values of the females show no significant changes ( $\mathrm{P} \geq 0.05)$ among all periods. Regarding the different levels of PSP, the results indicated that the level $6 \mathrm{~g}$ PSP $/ \mathrm{kg}$ diet recorded the highest $(\mathrm{P} \leq 0.01)$ and the lowest values in HSI of male and female, respectively, comparing to the other levels. However, the activity of liver enzymes (AST and ALT) were increased $(\mathrm{P} \leq 0.01)$ with increasing periods and levels of PSP, which revealed that the fish treated for 60 days and level $8 \mathrm{~g}$ PSP/ kg diet recorded the best $(\mathrm{P} \leq 0.01)$ values of AST and ALT.

Table 3: The overall means of different levels of PSP and different exposure periods on HSI (male and female) and liver enzymes (ALT and AST) of adult Nile tilapia during the rearing period

\begin{tabular}{|c|c|c|c|c|}
\hline \multirow{2}{*}{ Treat. } & \multicolumn{2}{|c|}{ HSI (\%) } & \multicolumn{2}{c|}{ Liver enzymes } \\
\cline { 2 - 5 } & Male & Female & AST (IU/L) & ALT (IU/L) \\
\hline Period (day) & \multicolumn{4}{|c|}{} \\
\hline 15 & $3.65^{\mathrm{b}}$ & 3.22 & $35.25^{\mathrm{C}}$ & $24.19^{\mathrm{C}}$ \\
\hline 30 & $4.24^{\mathrm{a}}$ & 3.22 & $39.07^{\mathrm{BC}}$ & $31.49^{\mathrm{B}}$ \\
\hline 45 & $3.63^{\mathrm{b}}$ & 3.29 & $44.67^{\mathrm{AB}}$ & $35.55^{\mathrm{AB}}$ \\
\hline 60 & $3.38^{\mathrm{b}}$ & 3.33 & $49.85^{\mathrm{A}}$ & $38.63^{\mathrm{A}}$ \\
\hline \pm SE & 0.196 & 0.127 & 2.987 & 1.695 \\
\hline P- value & 0.025 & 0.911 & 0.0075 & 0.0001 \\
\hline Level (g / kg diet) & $2.96^{\mathrm{C}}$ & $3.44^{\mathrm{A}}$ & $27.07^{\mathrm{C}}$ & $24.23^{\mathrm{C}}$ \\
\hline 0 & $3.95^{\mathrm{AB}}$ & $3.16^{\mathrm{AB}}$ & $39.88^{\mathrm{B}}$ & $28.03^{\mathrm{C}}$ \\
\hline 2 & $3.92^{\mathrm{AB}}$ & $3.41^{\mathrm{A}}$ & $43.89^{\mathrm{B}}$ & $33.90^{\mathrm{B}}$ \\
\hline 4 & $3.98^{\mathrm{A}}$ & $2.85^{\mathrm{B}}$ & $46.13^{\mathrm{AB}}$ & $36.49^{\mathrm{AB}}$ \\
\hline 6 & $3.42^{\mathrm{BC}}$ & $3.46^{\mathrm{A}}$ & $54.10^{\mathrm{A}}$ & $39.67^{\mathrm{A}}$ \\
\hline 8 & 0.219 & 0.142 & 3.340 & 1.895 \\
\hline \pm SE & 0.0006 & 0.01 & 0.0001 & 0.0001 \\
\hline P- value &
\end{tabular}

Means in the same column having different capital or small letters are significantly differ at $(\mathrm{P} \leq 0.01)$ and $(\mathrm{P} \leq 0.05)$, respectively; $\mathrm{SE}=$ Standard error; $\mathrm{P}$ - value $=$ Probability value.

The interaction between different levels of PSP and different exposure periods on HSI (male and female) and liver enzymes (AST and ALT) during the rearing period were presented in Table (4). The results indicated that the adult male and female Nile tilapia treated with levels $6 \mathrm{~g}$ PSP/kg for 30 days and $4 \mathrm{~g}$ PSP/kg diet for 60 days gave the highest $(\mathrm{P} \leq 0.01)$ values of HIS for male and female, respectively among all treatments. On the other hand, fish treated with $8 \mathrm{~g}$ PSP / kg diet for 60 days showed the highest $(\mathrm{P} \leq 0.01) \mathrm{v}$ alue of ALT among other treatments, while there were no significant $(\mathrm{P} \geq 0.05)$ effects on AST in all treatments. 
Table 4: The interaction between different levels of PSP and different exposure period on HSI (male and female) and liver enzymes (AST and ALT) of adult Nile tilapia during the rearing period

\begin{tabular}{|c|c|c|c|c|c|}
\hline \multirow{2}{*}{$\begin{array}{c}\text { Level } \\
\text { (g / kg diet) }\end{array}$} & \multirow{2}{*}{$\begin{array}{c}\text { Period } \\
\text { (day) }\end{array}$} & \multicolumn{2}{|c|}{ HSI (\%) } & \multicolumn{2}{|c|}{ Liver enzymes } \\
\hline & & Male & Female & AST (IU/L) & ALT (IU/L) \\
\hline 0 & \multirow{5}{*}{15} & $2.96^{\mathrm{B}}$ & $3.44^{\mathrm{AB}}$ & 27.07 & $24.23^{\mathrm{FG}}$ \\
\hline 2 & & $3.56^{\mathrm{B}}$ & $3.53^{\mathrm{AB}}$ & 31.00 & $26.77^{\mathrm{EFG}}$ \\
\hline 4 & & $3.88^{\mathrm{B}}$ & $2.66^{\mathrm{AB}}$ & 36.77 & $14.80^{\mathrm{G}}$ \\
\hline 6 & & $4.24^{\mathrm{B}}$ & $3.47^{\mathrm{AB}}$ & 37.00 & $28.90^{\mathrm{DEF}}$ \\
\hline 8 & & $3.62^{\mathrm{B}}$ & $3.01^{\mathrm{AB}}$ & 44.40 & $26.27^{\mathrm{EFG}}$ \\
\hline 0 & \multirow{5}{*}{30} & $2.96^{\mathrm{B}}$ & $3.44^{\mathrm{AB}}$ & 27.07 & $24.23^{\mathrm{FG}}$ \\
\hline 2 & & $4.13^{\mathrm{B}}$ & $2.95^{\mathrm{AB}}$ & 37.50 & $27.00^{\mathrm{EFG}}$ \\
\hline 4 & & $3.96^{\mathrm{B}}$ & $3.26^{\mathrm{AB}}$ & 40.80 & $33.80^{\mathrm{BCDEF}}$ \\
\hline 6 & & $6.64^{\mathrm{A}}$ & $2.87^{\mathrm{AB}}$ & 40.80 & $37.50^{\mathrm{BCDE}}$ \\
\hline 8 & & $3.52^{\mathrm{B}}$ & $3.55^{\mathrm{AB}}$ & 49.20 & $34.90^{\mathrm{BCDEF}}$ \\
\hline 0 & \multirow{5}{*}{45} & $2.96^{\mathrm{B}}$ & $3.44^{\mathrm{AB}}$ & 27.07 & $24.23^{\mathrm{FG}}$ \\
\hline 2 & & $4.29^{\mathrm{AB}}$ & $2.76^{\mathrm{AB}}$ & 43.00 & $27.10^{\mathrm{EFG}}$ \\
\hline 4 & & $4.01^{\mathrm{B}}$ & $3.66^{\mathrm{AB}}$ & 46.00 & $42.50^{\mathrm{ABC}}$ \\
\hline 6 & & $3.36^{\mathrm{B}}$ & $2.68^{\mathrm{AB}}$ & 48.30 & $38.90^{\mathrm{BCDE}}$ \\
\hline 8 & & $3.52^{\mathrm{B}}$ & $3.89^{\mathrm{AB}}$ & 59.00 & $45.00^{\mathrm{AB}}$ \\
\hline 0 & \multirow{5}{*}{60} & $2.96^{\mathrm{B}}$ & $3.44^{\mathrm{AB}}$ & 27.07 & $24.23^{\mathrm{FG}}$ \\
\hline 2 & & $3.84^{\mathrm{B}}$ & $3.40^{\mathrm{AB}}$ & 48.00 & $31.27^{\mathrm{CDEF}}$ \\
\hline 4 & & $3.81^{\mathrm{B}}$ & $4.04^{\mathrm{A}}$ & 52.00 & $44.50^{\mathrm{AB}}$ \\
\hline 6 & & $3.29^{\mathrm{B}}$ & $2.37^{\mathrm{B}}$ & 58.40 & $40.67^{\mathrm{ABCD}}$ \\
\hline 8 & & $3.01^{\mathrm{B}}$ & $3.39^{\mathrm{AB}}$ & 63.80 & $52.50^{\mathrm{A}}$ \\
\hline \multicolumn{2}{|c|}{$\pm \mathrm{SE}$} & 0.622 & 0.439 & 6.680 & 3.791 \\
\hline \multicolumn{2}{|c|}{ P- value } & 0.0005 & 0.013 & 0.9773 & 0.010 \\
\hline
\end{tabular}

Means in the same column having different capital letters are significantly differ at $(\mathrm{P} \leq 0.01)$.

$\mathrm{SE}=$ Standard error; $\mathrm{P}$ - value $=$ Probability value

\section{Total cholesterol, sex hormones and gonadosomatic index (GSI):}

Total cholesterol, sex hormones (testosterone and progesterone) and gonadosomatic index (GSI) of adult males and females Nile tilapia fed on different levels of PSP for different exposure periods are illustrated in Table (5). About the different periods, there were no significan (P05) effects on cholesterol, testosterone and progesterone hormones among all periods. Fish fed PSP for 45 and 60 days recorded the highest and the lowes $K$ (B.05) values in GSI of males, respectively. While, the exposure periods 60 and 30 day gave the highest and the lowest $(\mathrm{P} \leq 0.05)$ values in GSI of female, respectively, among other exposure periods.

Regarding the different levels of PSP, the results indicated that the levels 2, 8 and $4 \mathrm{~g} P S P / \mathrm{kg}$ diet recorded the better $(\mathrm{P} \leq 0.01)$ values in total cholesterol among other levels. On the other side, the testosterone and progesterone hormone values were decreased $(\mathrm{P} \leq 0.01)$ by increasing levels of $\mathrm{PSP}$, but the control group $\mathrm{L}_{0}(0 \mathrm{~g}$ $\mathrm{PSP} / \mathrm{kg}$ diet $)$ had the highest $(\mathrm{P} \leq 0.01)$ values than all treatments. However, fish fed levels 4 and $2 \mathrm{~g}$ PSP / $\mathrm{kg}$ diet gave the highest $(\mathrm{P} \leq 0.01)$ values in GSI of male and female, respectively, among all levels of PSP. 
Table 5: The overall means of different levels of PSP and different exposure periods on total cholesterol, GSI and sex hormones of adult male and female Nile tilapia during the rearing period

\begin{tabular}{|c|c|c|c|c|c|}
\hline \multirow{2}{*}{ Treat. } & \multirow{2}{*}{$\begin{array}{c}\text { Total Cholesterol } \\
\text { (mg/dl) }\end{array}$} & \multirow{2}{*}{$\begin{array}{c}\text { Testosterone } \\
\text { (ng/ml) }\end{array}$} & \multirow{2}{*}{$\begin{array}{l}\text { Progesterone } \\
\text { (ng/ml) }\end{array}$} & \multicolumn{2}{|c|}{ GSI (\%) } \\
\hline & & & & Male & Female \\
\hline \multicolumn{6}{|c|}{ Period (day) } \\
\hline 15 & 60.65 & 1.186 & 0.292 & $0.679^{\mathrm{ab}}$ & $2.90^{\mathrm{A}}$ \\
\hline 30 & 60.28 & 0.888 & 0.269 & $0.685^{\mathrm{ab}}$ & $1.62^{\mathrm{B}}$ \\
\hline 45 & 64.13 & 0.664 & 0.246 & $0.735^{\mathrm{a}}$ & $2.80^{\mathrm{A}}$ \\
\hline 60 & 57.99 & 0.716 & 0.242 & $0.574^{b}$ & $3.04^{\mathrm{A}}$ \\
\hline$\pm \mathrm{SE}$ & 2.121 & 0.155 & 0.040 & 0.040 & 0.278 \\
\hline P-value & 0.248 & 0.093 & 0.808 & 0.049 & 0.002 \\
\hline \multicolumn{6}{|c|}{ Level (g / kg diet) } \\
\hline 0 & $49.40^{\mathrm{B}}$ & $1.669^{\mathrm{A}}$ & $1.113^{\mathrm{A}}$ & $0.520^{\mathrm{B}}$ & $1.90^{\mathrm{B}}$ \\
\hline 2 & $69.01^{\mathrm{A}}$ & $1.101^{\mathrm{B}}$ & $0.062^{\mathrm{B}}$ & $0.551^{\mathrm{B}}$ & $3.73^{\mathrm{A}}$ \\
\hline 4 & $63.29^{A}$ & $0.602^{\mathrm{C}}$ & $0.053^{\mathrm{B}}$ & $0.837^{\mathrm{A}}$ & $2.17^{\mathrm{B}}$ \\
\hline 6 & $55.50^{\mathrm{B}}$ & $0.515^{\mathrm{C}}$ & $0.049^{\mathrm{B}}$ & $0.821^{\mathrm{A}}$ & $2.39^{\mathrm{B}}$ \\
\hline 8 & $66.63^{\mathrm{A}}$ & $0.430^{\mathrm{C}}$ & $\mathbf{0 . 0 3 4 ^ { \mathrm { B } }}$ & $0.613^{\mathrm{B}}$ & $2.77^{\mathrm{B}}$ \\
\hline$\pm \mathrm{SE}$ & 2.371 & 0.173 & 0.045 & 0.044 & 0.311 \\
\hline P-value & 0.0001 & 0.0001 & 0.0001 & 0.0001 & 0.001 \\
\hline
\end{tabular}

Means in the same column having different capital or small letters are significantly differ at ( $\underline{\mathrm{R}} 0.01)$ and $(\mathrm{P} \leq 0.05)$, respectively; $\mathrm{SE}=$ Standard error; $\mathrm{P}$ - value $=$ Probability value

The interaction between different levels of PSP and different exposure periods on total cholesterol, sex hormones (testosterone and progesterone) and gonadosomatic index (GSI) of adult males and females Nile tilapia during the rearing period were presented in Table (6). The results indicated that fish fed $2 \mathrm{~g}$ PSP / kg diet for 45 day recorded the highest $(\mathrm{P} \leq 0.01)$ values in total cholesterol among all treatments. While, the control group recorded the highest ( $\Phi 0.01)$ values of sex hormones (testosterone and progesterone) compared with different PSP-treated groups. On the other hand, fish fed $6 \mathrm{~g}$ PSP/ kg diet for 30 day and 2 g PSP/ kg diet for 60 day recorded the highest ( $\mathrm{B} \leq 0.01$ 1) values of GSI of males and females, respectively. While, fish fed $2 \mathrm{~g}$ PSP/ $\mathrm{kg}$ diet for 30 day gave the lowest $(\mathrm{P} \leq 0.01)$ values of GSI of males and females among all treatments. 
Table 6: The interaction between different levels of PSP and different exposure period on total cholesterol, sex hormones and GSI of adult male and female Nile tilapia during the rearing period

\begin{tabular}{|c|c|c|c|c|c|c|}
\hline \multirow{2}{*}{$\begin{array}{c}\text { Level } \\
\text { (g/kg diet) }\end{array}$} & \multirow{2}{*}{$\begin{array}{c}\text { Period } \\
\text { (day) }\end{array}$} & \multirow{2}{*}{$\begin{array}{c}\text { Total } \\
\text { Cholesterol } \\
\text { (mg/dl) }\end{array}$} & \multirow{2}{*}{$\begin{array}{l}\text { Testosterone } \\
\text { (ng/ml) }\end{array}$} & \multirow{2}{*}{$\begin{array}{c}\text { Progesterone } \\
\text { (ng/ml) }\end{array}$} & \multicolumn{2}{|c|}{ GSI (\%) } \\
\hline & & & & & Male & Female \\
\hline $\mathbf{0}$ & \multirow{5}{*}{15} & $\mathbf{4 9 . 4 0}^{\mathrm{EF}}$ & $1.67^{\mathrm{A}}$ & $1.11^{\mathrm{A}}$ & $0.520^{\mathrm{BCD}}$ & $1.90^{\mathrm{BCD}}$ \\
\hline 2 & & 63.97 ${ }^{\mathrm{BCDE}}$ & $1.39^{\mathrm{ABCD}}$ & $0.12^{\mathrm{B}}$ & $\mathbf{0 . 6 2 0}{ }^{\mathrm{ABCD}}$ & $4.51^{\mathrm{AB}}$ \\
\hline 4 & & $\mathbf{5 7 . 4 0 ^ { \mathrm { DEF } }}$ & $1.60^{\mathrm{AB}}$ & $0.08^{B}$ & $0.917^{\mathrm{AB}}$ & $2.63^{\mathrm{BCD}}$ \\
\hline 6 & & $\mathbf{6 2 . 5 0}^{\mathrm{BCDE}}$ & $\mathbf{0 . 8 8 ^ { \mathrm { ABCDE } }}$ & $0.08^{\mathrm{B}}$ & $\mathbf{0 . 7 0 0}{ }^{\mathrm{ABCD}}$ & $2.15^{\mathrm{BCD}}$ \\
\hline 8 & & $\mathbf{7 0 . 0 0} 0^{\mathrm{ABCD}}$ & $\mathbf{0 . 3 8 ^ { \mathrm { CDE } }}$ & $0.08^{B}$ & $\mathbf{0 . 6 4 0}{ }^{\mathrm{ABCD}}$ & $3.32^{\mathrm{ABCD}}$ \\
\hline $\mathbf{0}$ & \multirow{5}{*}{30} & $\mathbf{4 9 . 4 0 ^ { \mathrm { EF } }}$ & $1.67^{\mathrm{A}}$ & $1.11^{\mathrm{A}}$ & $\mathbf{0 . 5 2 0}{ }^{\mathrm{BCD}}$ & $1.90^{\mathrm{BCD}}$ \\
\hline 2 & & $\mathbf{6 0 . 5 0} 0^{\mathrm{BCDE}}$ & $1.47^{\mathrm{ABC}}$ & $0.07^{\mathrm{B}}$ & $0.280^{\mathrm{D}}$ & $0.35^{\mathrm{D}}$ \\
\hline 4 & & 74.50 ${ }^{\mathrm{AB}}$ & $\mathbf{0 . 5 1} 1^{\mathrm{ABCDE}}$ & $0.07^{\mathrm{B}}$ & $0.960^{\mathrm{AB}}$ & $\mathbf{2 . 6 8 ^ { \mathrm { BCD } }}$ \\
\hline 6 & & $43.50^{\mathrm{F}}$ & $\mathbf{0 . 4 2} 2^{\mathrm{CDE}}$ & $\mathbf{0 . 0 7} 7^{\mathrm{B}}$ & $1.060^{\mathrm{A}}$ & $1.15^{\mathrm{CD}}$ \\
\hline 8 & & $73.50^{\mathrm{ABC}}$ & $\mathbf{0 . 3 8 ^ { \mathrm { CDE } }}$ & $0.02^{\mathrm{B}}$ & $\mathbf{0 . 6 0 3} 3^{\mathrm{ABCD}}$ & $2.04^{B C D}$ \\
\hline $\mathbf{0}$ & \multirow{5}{*}{45} & $\mathbf{4 9 . 4 0}^{\mathrm{EF}}$ & $1.67^{\mathrm{A}}$ & $1.11^{\mathrm{A}}$ & $\mathbf{0 . 5 2 0}{ }^{\mathrm{BCD}}$ & $1.90^{\mathrm{BCD}}$ \\
\hline 2 & & $81.47^{\mathrm{A}}$ & $\mathbf{0 . 7 1} \mathbf{A B C D E}^{\mathrm{ABC}}$ & $0.03^{\mathrm{B}}$ & $0.523^{\mathrm{BCD}}$ & $3.83^{\mathrm{ABC}}$ \\
\hline 4 & & 63.30 ${ }^{\mathrm{BCDE}}$ & $0.09^{\mathrm{E}}$ & $0.03^{\mathrm{B}}$ & $\mathbf{0 . 8 7 0}^{\mathrm{ABC}}$ & $2.67^{\mathrm{BCD}}$ \\
\hline 6 & & $\mathbf{5 5 . 5 0} 0^{\mathrm{DEF}}$ & $\mathbf{0 . 3 9} 9^{\mathrm{CDE}}$ & $0.03^{\mathrm{B}}$ & $0.973^{\mathrm{AB}}$ & $\mathbf{2 . 8 8 ^ { \mathrm { BCD } }}$ \\
\hline 8 & & 71.00 ${ }^{\mathrm{ABCD}}$ & $\mathbf{0 . 4 7} 7^{\mathrm{BCDE}}$ & $\mathbf{0 . 0 2} 2^{\mathrm{B}}$ & $\mathbf{0 . 7 9 0}{ }^{\mathrm{ABC}}$ & $2.73^{\mathrm{BCD}}$ \\
\hline $\mathbf{0}$ & \multirow{5}{*}{60} & $\mathbf{4 9 . 4 0}^{\mathrm{EF}}$ & $1.67^{\mathrm{A}}$ & $1.11^{\mathrm{A}}$ & $\mathbf{0 . 5 2 0} 0^{\mathrm{BCD}}$ & $1.90^{\mathrm{BCD}}$ \\
\hline 2 & & $\mathbf{7 0 . 1 0}{ }^{\mathrm{ABCD}}$ & $\mathbf{0 . 8 3}{ }^{\mathrm{ABCDE}}$ & $0.03^{\mathrm{B}}$ & $\mathbf{0 . 7 8 0}{ }^{\mathrm{ABC}}$ & $6.24^{\mathrm{A}}$ \\
\hline 4 & & $\mathbf{5 7 . 9 7}{ }^{\mathrm{CDEF}}$ & $\mathbf{0 . 2 1} 1^{\mathrm{DE}}$ & $0.03^{\mathrm{B}}$ & $\mathbf{0 . 6 0 0}{ }^{\mathrm{ABCD}}$ & $\mathbf{0 . 6 9} 9^{\mathrm{CD}}$ \\
\hline 6 & & $\mathbf{6 0 . 5 0}^{\mathrm{BCDE}}$ & $\mathbf{0 . 3 8 ^ { \mathrm { CDE } }}$ & $0.02^{\mathrm{B}}$ & $0.550^{\mathrm{BCD}}$ & $3.38^{\mathrm{ABCD}}$ \\
\hline 8 & & $52.00^{\mathrm{EF}}$ & $\mathbf{0 . 4 9} \mathbf{9}^{\mathrm{ABCDE}}$ & $0.02^{\mathrm{B}}$ & $0.420^{\mathrm{CD}}$ & $2.99^{\mathrm{ABCD}}$ \\
\hline \multicolumn{2}{|l|}{ SE } & 4.742 & 0.347 & 0.091 & 0.089 & 0.622 \\
\hline \multicolumn{2}{|l|}{$\operatorname{Pr}>F$} & 0.0030 & 0.009 & 0.002 & 0.0005 & 0.0005 \\
\hline
\end{tabular}

Means in the same column having different capital letters are significantly differ at (P 0.01); SE = Standard error; P- value $=$ Probability value.

\section{Histological examination of the gonads:}

Testis:

The histological examination of testis of adult male $O$. niloticus fed different levels of PSP on different exposure periods showed in Figure $1(\mathrm{a}-\mathrm{h})$. Results showed that the control group $T_{1}, T_{2}, T_{3}$ and $T_{4}$ appeared normal structure of semniferous tubules filed with spermatocytes (scy) (Fig. 1a). While, the treatments $T_{5}$ and $\mathrm{T}_{6}$ ( $2 \mathrm{~g}$ PSP / kg diet for 15 and 30 days, respectively) led to severe degeneration (arrows) and autolysis (stars) of semniferous tubules (Fig. 1b). Also, addition of $2 \mathrm{~g}$ PSP / kg diet for 45 and 60 days ( $\mathrm{T}_{7}$ and $\mathrm{T}_{8}$, respectively) and $2 \mathrm{~g}$ PSP / kg diet for 30,45 and 60 days ( $T_{10}, T_{11}$ and $T_{12}$, respectively) showing degeneration (arrows) of semniferous tubules (Fig. 1c). The treatment $\mathrm{T}_{9}$ (4 g PSP / kg diet for 15 days) showed necrosis (arrows) and very severe autolysis (stars) of semniferous tubules (Fig. 1d). On the other hand, $\mathrm{T}_{13}$ (4g PSP / kg diet for 15 days) and $\mathrm{T}_{15}$ (6g PSP / kg diet for 45 days) showed degeneration (arrows) and fibrosis (arrows heads) of semniferous tubules (Fig. 1e). Also, $\mathrm{T}_{14}$ and $\mathrm{T}_{16}$ (6g PSP / kg diet for 30 and 60 days, respectively); $\mathrm{T}_{17}$ and $\mathrm{T}_{19}$ (8g PSP / $\mathrm{kg}$ diet for 15 and 45 days, respectively) showed degeneration (arrows), fibrosis (arrow head) and large area of severe autolysis (stars) of semniferous tubules (Fig. 1f). In the same trend, $\mathrm{T}_{18}$ showed autolysis (stars) and large areas of degeneration (arrows) and fibrosis (arrow head) of semniferous tubules (Fig. 1g). Furthermore, $T_{20}$ showed severe necrosis (arrows heads) and large areas of very severe degeneration (arrows) of semniferous tubules with completely empty of spermatocytes (scy) in testes lumen (Fig. 1h). 


\section{Ovary:}

The histological examination of ovaries of adult female $O$. niloticus fed different levels of PSP on different periods showed in Figure $2(\mathrm{a}-\mathrm{h})$. The control groups $\left(T_{1}, T_{2}, T_{3}\right.$ and $\left.T_{4}\right)$ showed normal structure of ovarian lamellae, which contains oocytes at various stages of oogenesis (Fig. $2 \mathrm{a}$ ). Treatments $\mathrm{T}_{5}$ and $\mathrm{T}_{7}(2 \mathrm{~g}$ PSP / kg diet for 15 and 45 days, respectively), $\mathrm{T}_{9}$ and $\mathrm{T}_{12}$ (4 g PSP / kg diet for 15 and 60 days, respectively) and $\mathrm{T}_{13}$ ( $6 \mathrm{~g}$ PSP $/ \mathrm{kg}$ diet for 15 days) let to large areas of severe degeneration (stars) of the cytoplasm of oocytes (Fig. $2 \mathrm{~b}$ ). Also, $\mathrm{T}_{6}$ and $\mathrm{T}_{8}(2 \mathrm{~g}$ PSP/ diet for 30 and 60 days, respectively), $\mathrm{T}_{10}$ (4 g PSP / kg diet for 30 days) and $\mathrm{T}_{19}$ (8 g PSP / kg diet for 45 days) showed severe degeneration (stars) of the cytoplasm, autolysis (arrows) in some oocytes (Fig. 2 c). In the same trend, $\mathrm{T}_{11}$ (4 g PSP $/ \mathrm{kg}$ diet for 45 days) and $\mathrm{T}_{14}$ (6 g PSP / kg diet for 30 days) showing absent of the nucleus walls and swell nucleolus (arrows heads), buckling (arrows) of oocytes walls and degeneration (stars) of the cytoplasm (Fig. $2 \mathrm{~d}$ ). The treatment, $\mathrm{T}_{15}(6 \mathrm{~g}$ PSP $/ \mathrm{kg}$ diet for 45 days) and $\mathrm{T}_{17}$ (8 $\mathrm{g}$ PSP $/ \mathrm{kg}$ diet for 15 days) showed elongation of the nucleus (arrow head), thickening and buckling of the oocytes walls (arrows) and degeneration (stars) of the cytoplasm (Fig. 2 e). Also, $\mathrm{T}_{16}$ (6 g PSP / kg diet for 60 days) showing severe degeneration (stars) of the cytoplasm, liquefy of the nucleus and buckling (arrow head) of the oocyte wall (Fig. 2 f). Nevertheless, $\mathrm{T}_{18}$ (8 g PSP /kg diet for 30 days) showing very severe degeneration of cytoplasm (stars), severe buckling (arrows) of the oocytes walls and liquefy of the nucleus (arrows heads) (Fig. 2 g). Meanwhile, $\mathrm{T}_{20}$ (8 g PSP $/ \mathrm{kg}$ diet for 60 days) showing empty and severe degeneration of oocytes (stars), severe thickening and buckling of the oocytes walls (arrows) and elongation of the nucleus (arrows heads) (Fig. $2 \mathrm{~h}$ ).

\section{DISCUSSION}

It is well know that the liver is metabolic organ. Thus, it is a target for the metabolism in the fish body. Therefore, the liver index (HSI) is a useful biomarker to detect the hazardous effects of the environmental stressors (Pait and Nelson, 2003). The results obtained in current study indicated the increasing of HSI in both male and female of Nile tilapia by increasing the levels of PSP in diets, which reflects negative effects of dietary PSP supplementation on the liver function enzymes (AST and ALT). Whereby, the two enzymes (ALT and AST) could be evaluating liver intoxication (Krajnovic-Ozretic, 1991). Thus, the biochemical analyses of serum constituents have proved to be useful in the diagnosis of metabolic disturbances and disease. This means that the increase in AST and ALT activities in PSP-treated fish might be attributed to pathological conditions for the liver, and the disturbances in the liver enzymes could be due to the inclusion of PSP on the toxic substance such as carpine (Ayotunde and Ofem, 2008). The present results are corresponding with the results obtained by Abbas and Abbas (2011) in Nile tilapia and Bolu et al. (2009) in the broilers chicken. In addition to the previous, it is important to mention that the differences in function of liver enzymes may be related to type of experimental food additives, toxic factors in the food additives, exposure time, experimental animal species, their age and nutritional and/or physiological statues.

The gonado-somatic index (GSI) has been a useful index for monitoring the progression of gametogenesis in teleost fish (Guerrero et al., 2009). In the present study, the GSI of male was increased with increasing the levels of PSP. Also, the significant $(\mathrm{P} \geq 0.01)$ increase and decrease of total cholesterol and testosterone, respectively which were detected, by increasing the levels of PSP compared with the 
control group; reflexed the forcing effects of PSP as sterilizing agent for controlling the reproductive performance of Nile tilapia. In addition, this adverse effect of PSP on sexual hormone was confirmed by the histological alterations of the testis of fish fed the different levels of PSP (Fig. 1), which increased by increasing the levels of PSP compared with the control group. Moreover, Van Denmark and Boyd (1996) speculated that a combination of enzymes, alkaloids and other substances in $C$. papaya might themselves inhibit testosterone production and ultimately oestrogen production. As far as the mechanism of the antifertility action is concerned, these observations indicated clearly that $C$. papaya seed extract acted indirectly on the anterior pituitary to inhibit gonadotrophin synthesis. In addition, an explanation for the decline of testosterone hormone level in male was given by Kusemiju et al. (2002) who also corroborate this finding, that $C$. papaya extract eliminated testosterone and other leydig cell factors required for steroidogenesis in male rats. There is a growing evidence to show that $C$. papaya causes the release of catecholamines, epinephrine and norepinephrine, from alpha-adrenergic receptors. Since catecholamines are known to induce gonadal inhibition, it has been suggested that they may interfere with the production of testosterone via this mechanism. This action was similar to that of antispermatogenic and antipituitary drugs which caused reduction in the sperm count (azoospermia and oligospermia) (Udoh et al., 2005a).

It is important to mention that the studies on $C$. papaya seeds extract on reproductive performance seem to be concentrated in male. The action of C. papaya seeds in female is impairment in the production of testosterone that (is a pre-hormone for oestrogen) is probably an indirect impairment on oestrogen production. Nevertheless, Raji et al. (2005) found that chloroform extract of C. papaya seed induced degeneration of the follicular wall, which may be responsible in part for the significant decrease estrogen level in serum. Likewise, the significant decrease of progesterone concentration by increasing the levels of PSP reflected the strong relationship with decreasing the gonadosomatic index (GSI) of adult female Nile tilapia compared with the control group. In addition, the estrogenic effects of PSP on adult Nile tilapia female may be confirmed by histological alterations of the ovary (Fig. 2) of fish treated with PSP, which showed increased the severity of histological alterations by increasing the level of PSP compared with the control group. These results are similar to those reported by (Lucidi et al., 2003 and Raji et al., 2005) of progesterone in rats female.

Gonadal development is a continuous process, but specific histological characteristics can be used to classify stages of gonadal development during the reproductive cycle (Bucholtz et al., 2008). Results of this study indicated that histological alterations of testis and ovaries in adult male and female of $O$. niloticus, respectively increased with increasing the levels of PSP in diets or exposure periods. The high levels 4, 6 and $8 \mathrm{~g}$ PSP / kg diet or increasing exposure periods (30, 45 and 60 day) caused severe degeneration of semniferous tubules, severe necrosis and large area of severe autolysis of semniferous tubules compared with the control group (Fig. 1). Also in ovaries, the same trend, the high levels of PSP or exposure periods led to empty of oocytes, shrinkage and severe degeneration of the cytoplasm, elongation and disappearance of the wall of the nucleus, autolysis in some oocytes, buckling of the oocytes wall and liquefy of the nucleus (Fig. 2) in relation to the control group. From other hand, it could be noted that all of these histological alterations in testis and ovary of the experimental fish are due to dietary PSP levels and also are confirmable 
with those of the lower concentration of testosterone and progesterone hormones respectively, with increasing the levels of PSP and exposure periods.

In addition, these changes of testes and ovaries are due to the C. papaya extract of the sections of pituitary gonadotrophs (FSH and LH cells) caused pronounced hypertrophy, hyperplasia and gradual degeneration of germ cells, sertoli cells and leydig cells, as well as germinal epithelium. This disruptive effect could be direct or indirect via the pituitary-gonadal axis, or a direct or indirect effect of androgen on the tubules. Since the tubules require a high concentration of androgen for cell maturation and function, the disruption of the tubules could lead to a lower concentration of androgen and this could cause the histological changes observed in the tubules (Udoh and Kehinde, 1999 and Udoh et al., 2005a). Where, Adebiyi et al. (2003) attributed this effect to the degenerative activity of benzyl-isothiocyanate.

The present results were in agreement to explain the obtained results by Ekanem and Okoronkwo (2003) in male Nile tilapia; Ekanem and Bassey (2003) female Nile tilapia; Abbas and Abbas (2011) and Jegede and Fagbenro (2008) for Nile tilapia (male and female). The dose 2 to $8 \mathrm{~g} / \mathrm{kg}$ diet with exposure periods 15 to 60 day which used in present study differ than those used by previous studies. Furthermore, the previous studies used fish (O. niloticus) in average weight of $40 \mathrm{~g}$ after sexual maturation, while in the current study fry at average initial body weight $0.012 \mathrm{~g}$ was used at one day old after absorbing the yolk sac. Therefore, the histological changes of testis were more pronounced, where the exposure periods coincides with the stages of testicular configuration. Gonadal differentiation of tilapia appears to occur between 8 - 25 days post-hatch (Nakamura and Takahashi, 1973). Also, other medical herbs caused the same changes in the testis and ovaries of Nile tilapia such as Aloe vera latex (Jegede, 2009) and Hibiscus rosa-sinensis leaf (Jegede, 2010). On the other hand, the negative effect of papaya seeds on the histological structure of testes was also observed in laboratory animals, such as rats (Goyal et al., 2010) and rabbits (Lohiya et al., 1999).

In female, the active substance responsible for the antiimplantation effect of papaya seed is 5- hydroxytryptamine (Farnsworth et al., 1975). In addition, Adebiyi et al. (2003) suggested that the extracts of papaya seeds are capable of causing functional aberrations of different mammalian tissues/organs and systems probably due to the toxic effects of benzyl-isothiocyanate. In addition, Lucidi et al. (2003) suggested that steroidogenesis could be influenced by active development of the oocyte. It then follows that the atretic follicles in the histological sections could be due to a decrease in oestrogen level.

Generally, the obtained results in this study showed that the high levels of PSP (6 and $8 \mathrm{~g}$ PSP $/ \mathrm{kg}$ diet) on long exposure periods (45 and 60 day) in diets of Nile tilapia after hatching gave the positive effect to control of the reproductive process in $O$. niloticus through decreased the sex hormone (testosterone and progesterone) and caused several histological alternations in testis and ovaries, which reduced fertility in both males and females Nile tilapia. In addition, in the complementary study to the present study by Farrag et al. (2013) reported that the dietary PSP at level $6 \mathrm{~g} / \mathrm{kg}$ diet for 45 day after absorbing the yolk sac of Nile tilapia fry may be used as a growth promoter for tilapia fish, which improved the most of growth performance parameters, survival, FCR and fish body composition.

\section{CONCLUSIONS}

From the foregoing results, it could be recommended that the effectiveness use of pawpaw (C. papaya) seeds powder (PSP) as a natural reproductive inhibitor for $O$. 
niloticus. Also, further researches are needed on reducing the toxic effects of substances (carpaine) in PSP, which can allow use the high levels of PSP or reduce the exposure periods.

\section{REFERENCES}

Abbas, H.H. and Abbas, W.T. (2011). Assessment study on the use of pawpaw; Carica papaya seeds to control Oreochromis niloticus breeding. Pak. J. Biol. Sci., 14: 1117-1123.

Adebiyi, A.; Adaikan, P.G. and Prasad, R.N.V. (2003). Tocolytic and toxic activity of papaya seed extract on isolated rat uterus. Life Sci., 74: 581-592.

Ayotunde, E.O. and Ofem, B.O. (2008). Acute and chronic toxicity of pawpaw (Carica papaya) seed powder to Nile tilapia Oreochromis niloticus (Linne 1757), fingerlings. Afr. J. Biotechnol., 7 (13): 2265-2274.

Beardmore, J.A. (1996). Single sex super fish. Spore, 64: 6-16.

Bolu, S.A.O.; Sola-Ojo, F. E.; Olorunsanya, O.A. and Idris, K. (2009). Effect of graded levels of dried pawpaw (Carica papaya) seed on the performance, haematology, serum biochemistry and carcass evaluation of chicken Broilers. Int. J. Poultry Sci., 8 (9): 905-909.

Bucholtz, R.H.; Tomkiewicz, J. and Dalskov, J. (2008). Manual to determine gonadal maturity of herring (Clupeaharengus L.). DTU Aqua-report 197-08, Charlottenlund: National Institute of Aquatic Resources. pp. 45.

Das, R.P. (1980). Effect of papaya seeds on the genital organs and fertility of male rats. Indian J. Exp. Biol., 18: 408- 409.

Duncan, D.B. (1955). Multiple ranges and multiple F-tests. Biometrics, 11:1-42.

Ekanem, S.B. and Bassey, P.O. (2003). Effect of pawpaw seed (Carica papaya) as antifertility agent in female Nile tilapia (Oreochromis niloticus). J. Aquac. Trop., 18 (2): 181-188.

Ekanem, S.B. and Okoronkwo, T.E. (2003). Pawpaw seed as fertility control agent on male Nile tilapia. Naga ICLARM Quarterly, 26 (2): 8-10.

Ellefson, R.D. and Caraway, W.T. (1976). Fundamentals of clinical chemistry. Ed. Tietz. N.W., p. 506.

El-Sayed, A.F.M., (2006). Tilapia Culture. CAB International, Wallingford, UK., pp: 304.

Fagbenro, O.A. (2002). Tilapia: fish for thought. $2^{\text {nd }}$ Inaugural Lecture, Federal University of Technology, Akure, Nigeria; pp.77.

FAO, Food and Agriculture Organization of the United Nations, (2010). The State of World Fisheries and Aquaculture 2010. Rome. 197pp.

Farnsworth, N.R.; Bingel, A.S.; Cordell, A.G.; Crane, A.F. and Fong, H.S. (1975). Potential value of plants as source of raw antifertility agents. I. J. Pharm. Sci., 64 (4): 535-592.

Farrag, F.H.; Khalil, F.F.; Mehrim, A.I. and Refaey, M.M.A. (2013). Pawpaw (Carica papaya) seeds powder in Nile tilapia (Oreochromis niloticus) diets: 1- growth performance, survival, feed utilization, carcass composition of fry and fingerlings. J. Animal and Poultry Prod., Mansoura Univ., 4 (6): 363 - 379.

GAFRD (2011). General Authority for Fish Resources Development yearbook, " Fish Statistics Book in 2011", Ministry of Agriculture and Land Reclamation, Cairo, Egypt, 106 pp.

Goyal, S.; Manivannan, B.; Ansari, A.S.; Jain, S.C. and Lohiya, N.K. (2010). Safety evaluation of long term oral treatment of methanol sub-fraction of the seeds of 
Carica papaya as a male contraceptive in albino rats. J. Ethnopharmacol., 127: 286-291.

Guerrero, H.Y.; Cardillo, E.; Poleo, G. and Marcano, D. (2009). Reproductive biology of freshwater fishes from the Venezulan floodplains. Fish Physiol. Biochem., 35: 189 - 196.

Guerrero, R.D. (1982). Control of tilapia reproduction. In: The biology and culture of Tilapia, Pullin, R.S.V. and Lowe-McConnell, R.H. (Eds.). ICLARM, Philippines, pp: 309-316.

Jangaard, P.M.; Ackman, R.G. and Spios, J.C. (1967). Seasonal studies of the fatty acids composition of cod liver flesh, roe and milt lipids. J. Fish Res. Bd. of Canada, 24: 613-627.

Jegede, T. (2009). Effects of Aloe vera (Liliaceae) on the gonad development in Nile tilapia Oreochromis niloticus (Linnaeus 1758). Better science, better fish, better life, Proceedings of the Ninth International Symposium on Tilapia in Aquaculture. Shanghai Ocean University, Shanghai, China: 22-24.

Jegede, T. (2010). Control of reproduction in Oreochromis niloticus (Linnaeus 1758) using hibiscus rosa-sinensis (linn.) leaf meal as reproduction inhibitor. J. Agr. Sci., 2 (4):149- 154.

Jegede, T. and Fagbenro, O. (2008). Histology of gonads in Oreochromis niloticus (Trewavas) fed pawpaw (Carica papaya) seed meal diets. $8^{\text {th }}$ International Symposium on Tilapia in Aquaculture, 1135 - 1141.

Krajnović-Ozretić, M. (1991). Serum enzymes in fish as biochemical indicators of marine pollution. MAP Technical Reports series No. 48. UNEP, Athens, 1-11.

Kusemiju, O.; Noronha, C. and Okanlawon, A. (2002). The effect of crude extract of the bark of Carica papaya on the semniferous tubules of male Sprague-Dawley rats. Niger Postgrad Med. J., 9 (4), 205-209.

Lohiya, N.K.; Manivannan, B.; Mishra, P.K.; Pathak, N.; Sriram, S.; Bhande, S.S. and Panneerdoss, S. (2002). Chloroform extract of Carica papaya seeds induces long-term reversible azoospermia in langur monkey. Asian J. Androl., 4: 17-26.

Lohiya, N.K.; Pathak, N.; Mishra, P.K. and Manivannan, B. (1999). Reversible contraception with chloroform extract of Carica papaya linn. seeds in male rabbits. Reprod. Toxicol., 13 (1): 59-66.

Lucidi, P.; Bemabo, N.; Turriani, M.; Mattioli, M. and Barboni, B. (2003). Cumulus steroido genesis is influenced by the degree of oocyte maturation. Reprod. Biol. Endocrinolol., 1: 45-55.

Mansour, C.R. (2001). Nutritional requirements of Nile tilapia broodstock reared at different water salinities. PhD. thesis, Alexandria University, Alexandria, Egypt.

Nakamura, M. and Takahashi, H. (1973). Gonadal sex differentiation in Tilapia mossambica, with special regard to the time of estrogen treatment effective in inducing complete feminization of genetic males. Bull. Fac. Fish. Hokkaido Univ., 24 (1); 1-13.

NRC (National Research Council) (1993). Nutrient requirements of fish. Committee on Animal Nutrition Board on Agriculture. National Academy Press, Washington DC., USA. 114pp.

Pait, A.S. and J.O. Nelson, 2003. Vitellogenesis in male Fundulus heteroclitus (Killifish) induced by selected estrogenic compounds. Aquat. Toxicol., 64: 331342.

Pathak, N.; Mishra, P.K.; Manivannan, B. and Lohiya, N.K. (2001). Prospects of developing a plant based male contraceptive pill. In: Current Status in Fertility Regulation: Indigenous and Modern Approaches, Chowdhary, S.R., Gupta, 
G.M. and Kamboj, V.P. (eds). Central Drug Research Institute: Lucknow, 99119.

Raji, Y.; Morakinyo, A.O.; Oloyo, A.K.; Akinsomisoye, O.S.; Kunle-Alabi, O.T.; Esegbue-Peters, P.R.C. and Awobajo, F.O. (2005). Impact of the chloroform extract of Carica papaya seed on oesterous cycle and fertility in female albino rats. J. Med. Sci., 5 (4): 337 - 343.

Reitman, S. and Frankel, S. (1957). Transaminase in serum. Am. J. Clin. Path., 28: 56-63.

Roberts, R.J. (2001). Fish Pathology, $3^{\text {rd }}$ edition, W.B. Saunders.

SAS (2006). SAS procedure user's guide. SAS Institute Inc., Cary, NC, USA.

Tietz, N.W. (1995). Clinical Guide to Laboratory Tests, 3rd Ed., W.B. Saunders Company, Philadelphia, PA 19106.

Tseng, W.Y. and Chan, K.L. (1982). The reproductive biology of the rabbit fish in Hong Kong. J. World Maricul. Soc., 13: 313-321.

Udoh, F.V.; Udoh, P.B. and Umoh, E.E. (2005b). Activity of Alkaloid extract of Carica papaya seeds on reproductive functions in male Wistar rats. Pharm. Biol., 43 (6): 563-567.

Udoh, P. and Kehinde, A. (1999). Studies on antifertility effect of pawpaw seeds (Carica papaya) on the gonads of male albino rats. Phytother. Res., 13: 226 228.

Udoh, P.; Essien, I. and Udoh, F. (2005a). Effects of Carica papaya (pawpaw) seeds extract on the morphology of pituitary-gonadal axis of male Wistar rats. Phytother. Res., 19: 1065-1068.

Van Denmark, N.L. and Boyd, L.J. (1996). The effect of epinephrme upon testicular functions in rabbits. Luterm. J. Fertility, 81: 245-247.

Yamazaki, F. (1983). Sex control and manipulation in fish. Aquaculture, 33:329-354. 


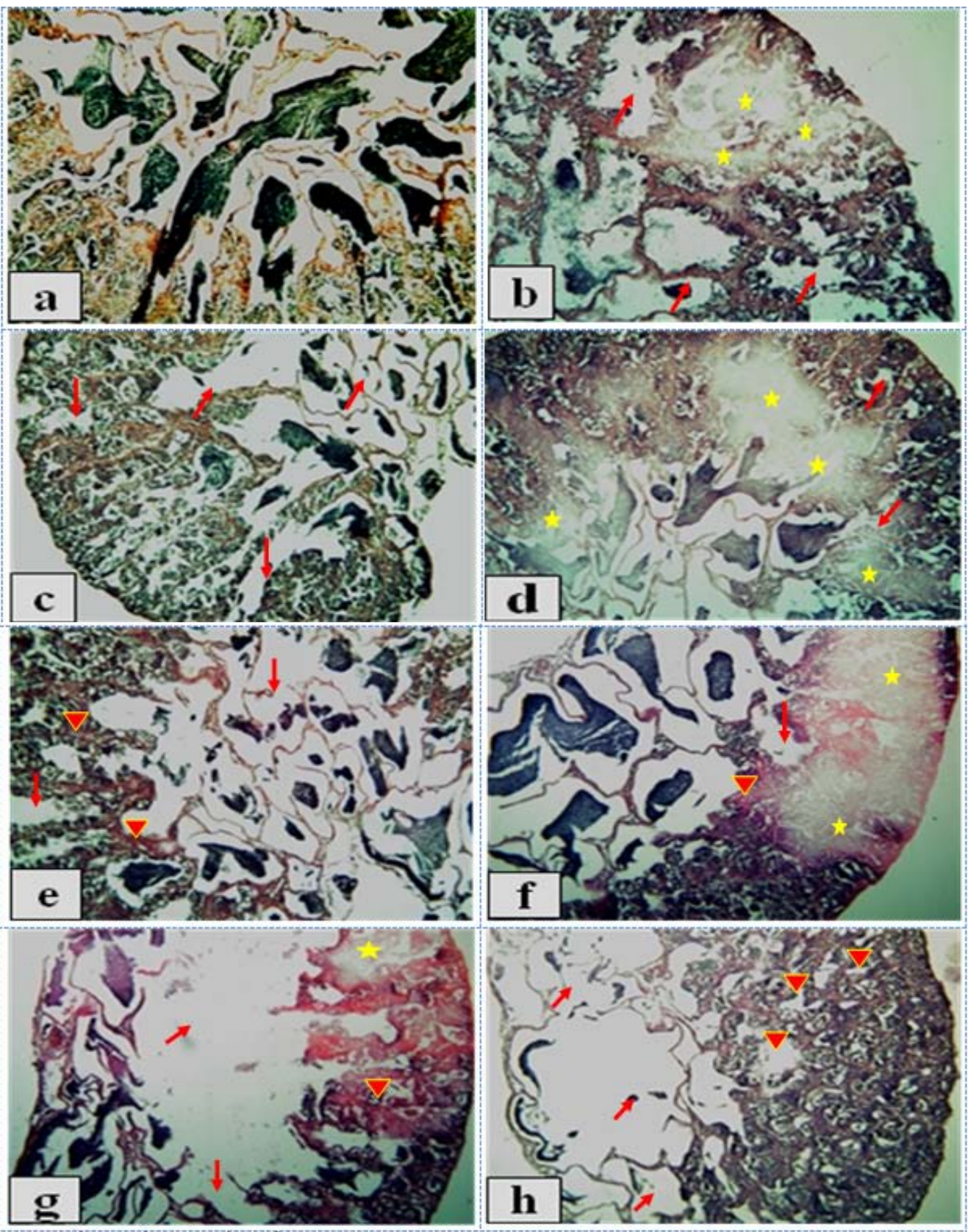

Fig. 1: Photomicrographs of transverse sections of testis of adult males O. niloticus (x 100, H\&E stains) (a) $T_{1}, T_{2}, T_{3}$ and $T_{4}$ (the control groups) showing normal structure of semniferous tubules; (b) $\mathrm{T}_{5}$ and $\mathrm{T}_{6}$ showing severe degeneration (arrows) and autolysis (stars) of semniferous tubules; (c) $\mathrm{T}_{7}, \mathrm{~T}_{8}, \mathrm{~T}_{10}, \mathrm{~T}_{11}$ and $\mathrm{T}_{12}$ showing degeneration of semniferous tubules (arrows); (d) $\mathrm{T}_{9}$ showing necrosis (arrows) and very severe autolysis (stars) of semniferous tubules; (e) $\mathrm{T}_{13}$ and $\mathrm{T}_{15}$ showing degeneration (arrows) and fibrosis (arrows heads) of semniferous tubules; (f) $\mathrm{T}_{14}, \mathrm{~T}_{16}, \mathrm{~T}_{17}$ and $\mathrm{T}_{19}$ showing degeneration (arrows), fibrosis (arrow head) and large area of severe autolysis (stars) of semniferous tubules; (g) $\mathrm{T}_{18}$ showing autolysis (stars) and large areas of degeneration (arrows) and fibrosis (arrow head) of semniferous tubules; (h) $\mathrm{T}_{20}$ showing severe necrosis (arrows heads) and large areas of very severe degeneration (arrows) of semniferous tubules. 


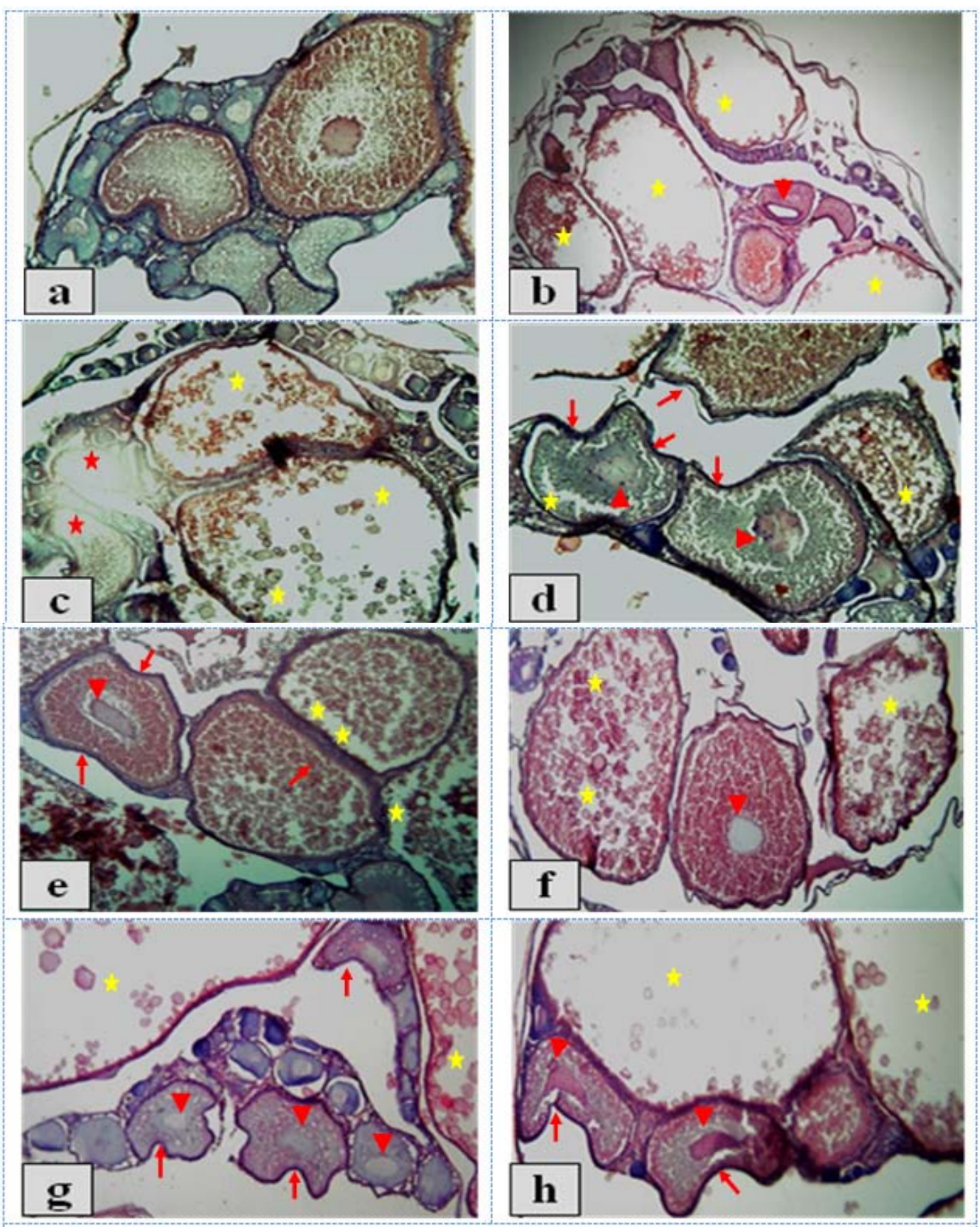

Fig. 2: Photomicrographs of transverse sections of ovaries of adult females O. niloticus (x 100, H\&E stains) (a) $T_{1}, T_{2}, T_{3}$ and $T_{4}$ (the control groups) showing normal structure of ovarian lamellae, which contains oocytes at various stages of oogenesis; (b) $T_{5}, T_{7}, T_{9}, T_{12}$ and $T_{13}$ showing large areas of severe degeneration (stars) of the cytoplasm of oocytes; (c) $\mathrm{T}_{6}, \mathrm{~T}_{8}, \mathrm{~T}_{10}$, and $\mathrm{T}_{19}$ showing severe degeneration (stars) of the cytoplasm, autolysis (two stars) in some oocytes; (d) $\mathrm{T}_{11}$ and $\mathrm{T}_{14}$ showing absent of the nucleus walls and swell nucleolus (arrows heads), buckling (arrows) of oocytes walls and degeneration (stars) of the cytoplasm; (e) $\mathrm{T}_{15}$ and $\mathrm{T}_{17}$ showing elongation of the nucleus (arrow head), thickening and buckling of the oocytes walls (arrows) and degeneration (stars) of the cytoplasm; (f) $\mathrm{T}_{16}$ showing severe degeneration (stars) of the cytoplasm, liquefy of the nucleus and buckling (arrow head) of the oocyte wall; (g) $\mathrm{T}_{18}$ showing very severe degeneration of cytoplasm (stars), severe buckling (arrows) of the oocytes walls and liquefy of the nucleus (arrows heads); (h) $\mathrm{T}_{20}$ showing empty and severe degeneration of oocytes (stars), severe thickening and buckling of the oocytes walls (arrows) and elongation of the nucleus (arrows heads). 


\title{
ARABIC SUMMRY
}

\section{مسحوق بذور الباباظ فى علاثق البلطى النيلى r ـ حالة الكبد و الهرمونات الجنسية و الفحص الهستولوجى للمناسل}

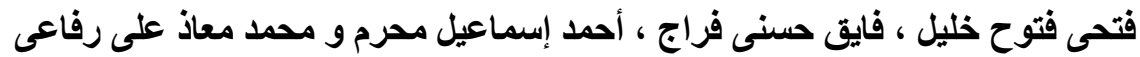

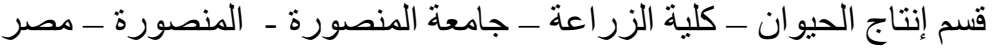

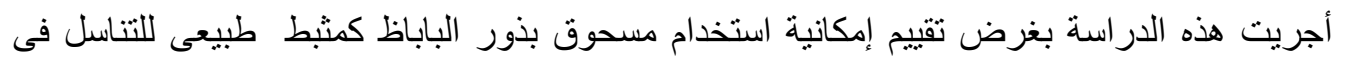

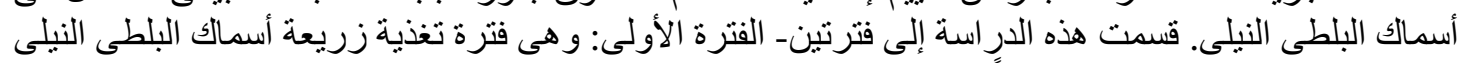

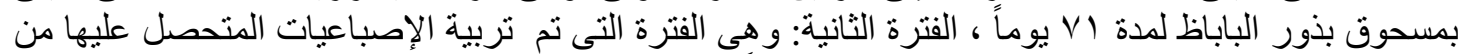

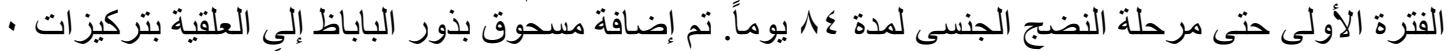

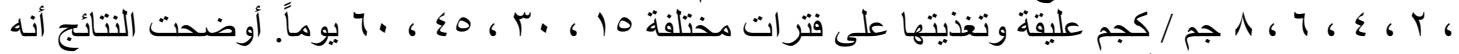

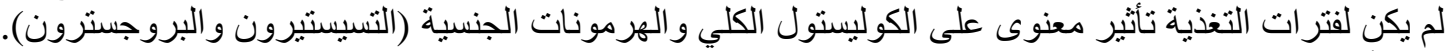

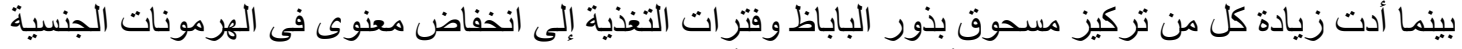

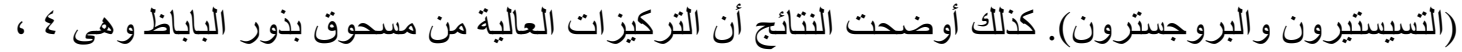

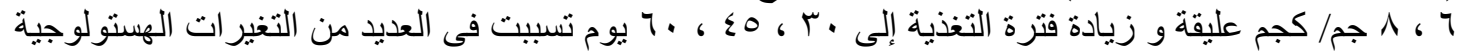

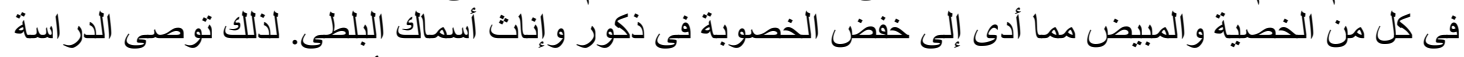

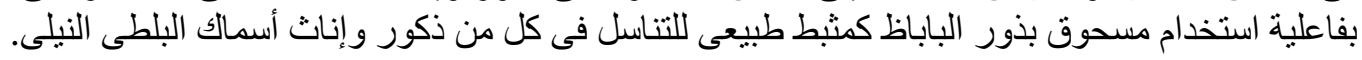

